\title{
Enhancing acclimatization of tissue cultured plants of Albizia amara by Biotization
}

\author{
G. Indravathi ${ }^{1,2^{*}}$, P. Suresh Babu ${ }^{3}$ \\ ${ }^{1}$ Dept. of Biotechnology, KVR Govt. College for Women (A), Kurnool, Andhra Pradesh, India \\ ${ }^{2}$ Dept. of Biotechnology, Jawaharlal Nehru Technological University, Anantapur, Andhra Pradesh, India \\ ${ }^{3}$ Department of Biology, Indian Institute of Science Education and Research, Tirupati, Andhra Pradesh, India \\ Corresponding author: gindravathi@gmail.com, Mobile No. : 9989067747
}

Available online at: www.isroset.org

Received: 20/Jul/2019, Accepted: 18/Aug/2019, Online: 31/Aug/2019

\begin{abstract}
The anatomical, morphological and physiological characteristics of the in vitro developed micro shoots, for a majority of the woody species, have a great impact on subsequent rooting and survival after transfer to greenhouse conditions. Any effort to improve these characteristics by controlling the stressful culture conditions undoubtedly contributes to better rooting of micro cuttings and/or acclimatization of the microplants. In the present investigation, timber yielding leguminous tree, Albizia amara has been selected for micropropagation owing to their, importance as a plant with potential medicinal value. Micropropagated plantlets usually exhibit high mortality rate upon their transfer from lab to land as a result of transplantation shock caused by abiotic and biotic stresses and weak root system. Biotization is the metabolic response of in vitro grown plant material to a microbial inoculum. It leads to morphological and physiological development of plant material thereby enhancing biotic and abiotic stress resistance.

The in vitro grown micro shoots of Albizia amara with root primordia were treated with bio inoculants namely - Pseudomonas fluorescens and Trichoderma viride and transferred to plastic pots containing sterilized potting mixture (soil: peat : vermiculite: perlite in 2:1:1:1). There were four treatments viz. control, treatment with T. viride and P. fluorescens separately and dual inoculation. Percent survival of plantlets was observed maximum (82\%) in dual inoculation, this must be due to the positive interaction between T.viride and $P$. fluorescens and their ability to enhance stress tolerance by protecting them from subsequent 'transplantation shock'. These plantlets also exhibited an increase in root length, the number of lateral roots, shoot length, leaf number, and plant biomass.
\end{abstract}

Keywords : Biotization,,micropropagation,acclimatization, A.amara, T. vi ride , P. fluorescens

\section{INTRODUCTION}

The genus Albizia, represented by over 100 species is confined to tropical or subtropical regions of Asia, Africa, and Australia. About 16 species are indigenous to the Indian subcontinent. Albizia species are cultivated as avenue trees, shade trees in tea and coffee plantation. Albizia species are socially significant for producing high-quality timber and as a valuable resource for gum yield. Albizia julibrissin, Albizia lebbeck, Albizia procera, and Albizia amara are some importantly considered species in Ayurvedic medicine. Albizia amara (Nallaregoo, Chigaraku) belonging to the family leguminaceae is a valuable economic medicinal and multipurpose drought-tolerant tree commonly found in dry forests of India.

In the present investigation, A. amara has been selected for micropropagation owing to their, importance as a plant with potential medicinal value. There are few preliminary reports on tissue culture of A.amara [1]. Shoot bud regeneration from leaf explants of A. amara was reported [2]. Micropropagation via axillary bud proliferation as described in A. amara, to regenerate true to type plantlets directly from seedling explants [3]. Limitations were observed in the acclimatization of micropropagated plants. The present proposal explores a reproducible and efficient protocol for enhancing the acclimatization of micropropagated plants by biohardening.

Tissue culture plants possess certain characteristic features i.e Culture Induced Phenotype due to their acclimatization to the special environment in vitro. High mortality is often observed upon transfer to ex vitro conditions as the cultured plants have nonfunctional stomata, weak root system, and poorly developed cuticle. As a result, they are subjected to transplantation shock caused both by abiotic and biotic stresses of the outside environment. Of these, biotic factors play an important role as the aseptically raised plants die due 
to their sudden exposure (particularly the root system) to the soil microflora.

Biotization is a bio-hardening technique where young in vitro raised plantlets are exposed to useful endophytes (both fungi \& bacteria) which invade the tissues of plants thereby promoting the growth of the host plants by the formation of secondary metabolites related to plant defense. Micro plant biotization is an emerging branch of science aimed at reducing chemical input in plant production whilst increasing plant fitness and productivity in the context of sustainable agriculture.

\section{RELATED WORK}

Rapid clonal multiplication of A.amara employing plant tissue culture was developed as problems with germination and recalcitrance nature of the tree is a constraint to natural regeneration. In the previous study, the development of complete plantlets via induction of multiple shoots from seedling derived cotyledonary node explant and their successful rooting was reported. But the successful transfer of in vitro raised plantlets to the soil during acclimatization was poor $(50 \%)$ due to premature defoliation of leaflets. The present proposal explores a reproducible and efficient protocol for enhancing the acclimatization of micropropagated plants by ex- vitro rooting and biohardening. The objective of this study was to determine the effect of high auxin dip and bio inoculants treatment on root induction (invitro), root elongation(ex vitro) and plant survival of invitro raised plantlets of A.amara during the acclimatization period.

\section{MATERIALS AND METHODS}

\section{Establishment of aseptic cultures -}

Cotyledonary node explants obtained from 15-d-old aseptically raised seedlings of A.amara were used for multiple shoot induction on MS medium containing $2.0 \%$ sucrose, $0.8 \%$ agar and BAP $\left(1 \mathrm{mg} \mathrm{L}^{-}\right.$

1 ). The explants were subcultured on the fresh medium after every 15 days for further shoot proliferation. Seeds of Albizia amara were procured in the month of April from SK University campus, Anantapur.

\section{Root induction:}

The micro shoots were separated from the multiple shoots proliferated from the cotyledonary nodal explant of aseptically raised seedlings of A.amara. The base of the micro shoots was immediately dipped in high concentrated auxin solution for 30-60 minutes. After this, the microcutting were grown in $1 / 4$ strength MS auxin free media in dark conditions for 6 to13 days for root induction at a temperature of $26-28{ }^{\circ} \mathrm{C}$.

\section{Microbial cultures:}

The fungus, Trichoderma viride (MTCC Code - 4329)used in the present study was grown on Potato Dextrose medium at $28 \pm 2^{\circ} \mathrm{C}$ for $10-12$ d. The bacterium, Pseudomonas fluorescens (MTCC Code - 8127), used as bioinoculant was grown on nutrient broth at $28 \pm 2^{\circ} \mathrm{C}$ for 24 hours. The pure culture of the samples was procured from IMTech, Chandigarh.

\section{Preparation of bio inoculants:}

Trichoderma viride cultures were streaked on potatodextrose agar medium and incubated at $28 \pm 2^{\circ} \mathrm{C}$ for $10-12 \mathrm{~d}$. The spores were scrapped and suspended in sterilized distilled water and used as inoculum at a density of $2 \times 10^{6}$ spores $/ \mathrm{ml}$. $P$. fluorescens was prepared in broth formulations containing $10^{6}$ Colony Forming Units $(\mathrm{CFU}) / \mathrm{ml}$.

The inoculation technique differs depending on the substratum or the nature of the inoculum used [4]. Selection of quantity [5-8] and quality of inoculum is an important point both for in vitro and in vivo mycorrhization [9]. The inoculum should not only be pure but also be able to exhibit the desired biological effect. In the recent past, hyphae, spores, chlamydospores, and mycorrhizal roots have been used as inocula by various mycorrhizologists for in vitro, as well as in vivo mycorrhization whereas, for bacteria, broth or diluted sample is used for inoculation [10-12].

\section{Treatment of Bioinoculants:}

To assess the efficacy of different bio-inoculants in increasing the in vivo establishment rate ,the micro-cutting with root primordia were taken out from the culture vessel, thoroughly washed with tap water to remove adhering agar, treated with bio-inoculants namely - Pseudomonas fluorescens and Trichoderma viride and transferred them to $200 \mathrm{~g}$ of sterilized potting mixture (soil: peat : vermiculite: perlite in $2: 1: 1: 1$ ) in plastic pots (two plantlets/pot). The plantlets were covered with plastic bags to maintain high humidity. The potting mix was moistened daily with $1 / 4^{\text {th }}$ MS salt solution. Humidity was gradually reduced (from $70-45 \%$ ) by making larger holes in the bags, later their covers were opened gradually. There were four treatments viz. uninoculated control, biotization with T.viride, $P$. fluorescens individually and dual inoculation i.e. T. viride + P. fluorescens. Initial data on percent plant survival were recorded after transplantation in shade conditions at different time intervals maintained at $28 \pm 2^{\circ} \mathrm{C}$ with $13 / 11$ hours light/dark regime with $65-70 \%$ Relative Humidity (RH).

A c c limatization Studies:

After one month the root colonized plantlets were transplanted into earthen pots containing soil, sand and 
farmyard manure $(1: 1: 1)$ and were allowed to grow under nursery shade conditions. The soil substrate must provide good aeration, water drainage and must have an appropriate temperature (higher than ambient) and the $\mathrm{pH}$ must be adjusted according to the requirements of the plant species concerned [13,14]. In a suitable substrate with the appropriate temperature, roots become functional and resume enhanced growth. Watering was done daily to maintain the relative humidity.

At the time of transplantation, various growth parameters were recorded from treated and untreated samples. Each experiment consisted of three replicates and 20 plantlets were used per treatment. Data was recorded 60 days after transfer of plants to pots.

\section{Plant Growth Measurement:}

The shoot length, leaf number, root number, root length, plant biomass, percent survival, root colonization of inoculated and non-inoculated plants were recorded after 60 days of microbial inoculation.

\section{Root Colonization:}

Plantlets were microscopically examined for T. viride colonization by staining the roots with the trypan blue method [15]. The fungus colonized roots of A.amara were washed under running tap water, cut into small pieces and boiled in $10 \% \mathrm{KOH}$ solution for $5 \mathrm{~min}$. Later they were washed 3-4 times with sterilized distilled water and treated with $1 \% \mathrm{HCl}$ for 3-4 min before staining with $0.05 \%$ trypan blue in lactophenol. The stained root segments were microscopically examined (100X). The roots of control plants were also processed and examined similarly. The population count of $P$. fluorescens was noted by using a standard serial dilution pour plate method [16].

\section{RESULTS}

\section{Plant Survival:}

Survival rate $\mathrm{w}$ as recorded after 15,30 and 60 $\mathrm{days}$ of transplantation in the greenhouse. Maximum percent survival was observed in plantlets with dual inoculation followed by single inoculations with T. viride and P. fluorescens over control (Figure). After two months of growth in the greenhouse, all the treated plants were transferred to the nursery. When transplanted to the greenhouse conditions after 60 days, $\mathrm{d}$ u a 1 inoculated plantlets showed better growth and higher survival percentage (82\%) than T.viride inoculated plantlets $(63 \%)$ and $P$. fluorescens inoculated plantlets (55\%).

\section{Microbial Colonization:}

Microscopic examination of infected stained roots revealed the presence of hyphae in the stained roots. Maximum root colonization of A.amara was observed in dual inoculated plants followed by single inoculation with T. viride or P. fluorescens after $30 \mathrm{~d}$ of biotization.

\section{Root-Shoot Length:}

After sixty days of growth in the greenhouse, a significant increase in root length and number of lateral roots was observed over control. An increase in shoot length and root length was recorded in all the treatments over control. Dual inoculation showed maximum shoot length and root length. Plantlets inoculated both with $T$.viride and $P$. fluorescens attained maximum shoot height of $12.56 \mathrm{~cm}$ and a root height $10.86 \mathrm{~cm}$. Plantlets inoculated only with $P$. fluorescens attained shoot height of $7.85 \mathrm{~cm}$ and root length of $4.84 \mathrm{~cm}$. Plantlets inoculated with $T$. viride attained shoot height of $9.56 \mathrm{~cm}$ and root length of $6.95 \mathrm{~cm}$. Dual inoculated plantlets also showed a significant increase in the number of roots (2.13) and root length $(10.86 \mathrm{~cm})$ per plantlet, which accounted for their improved growth. (Table).

\section{Leaf Number:}

In dual inoculated plants maximum leaf number was recorded followed by single inoculations. Plantlets inoculated both with T.viride and P. fluorescens has increased number of leaves (6.85) per plantlet. Plantlets inoculated with T.viride showed an average of 4.24 number of leaves per plantlet whereas $P$. fluorescens showed increased 4.83 number of leaves per plantlet as compared to control plantlets with 2.3 leaves per plantlet as observed after 2 months of their growth in the greenhouse (Table).

\section{Plant Biomass:}

T.viride and P. fluorescens treated plantlets also showed an increase in total plant biomass, fresh weight of $1.12 \mathrm{~g}$ and dry weight of $0.28 \mathrm{~g}$ per plantlet was recorded (Table ). P. fluorescens treated plantlets showed $0.79 \mathrm{~g}$ of total fresh weight and dry weight of $0.18 \mathrm{~g}$ whereas T.viride treated plantlets showed fresh weight $0.92 \mathrm{~g}$ and dry weight of $0.20 \mathrm{~g}$ per plantlet but less compared to dual inoculation.

\section{DISCUSSION}

\section{Effect of bio inoculants on plant survival and growth}

In general, micropropagated plants exhibit high mortality rates upon their transfer to soil. Even five percent of mortality causes an enormous loss during commercial plant production. The greenhouse and field possess comparatively lower humidity, higher light intensity and septic atmosphere that are stressful to micropropagated plants as compared to in vitro conditions [17]. The advantage of any micropropagation system may be accomplished only by the successful transfer of plantlets from in vitro conditions to the ambient conditions found $e x$ vitro. 
One of the distinctive features of this study was the incorporation of a bio-hardening step at the time of soil transplantation. Bio-inoculants such as Pseudomonas fluorescens and Trichoderma viride were found highly effective in improving the survival frequency. Use of bio inoculants throughout the acclimatization stage protected micropropagated young plantlets from 'transplantation shock'. Plant growth and biomass were greatly influenced by nutrients and environmental conditions. Plant survival was observed maximum in dual inoculation, this must be due to the positive interaction between T.viride and $P$. fluorescens and their ability to improve stress tolerance by protecting them from subsequent 'transplantation shock'. Pseudomonas strain PsJN increased the tolerance to transplanting stress in potato and was found to be the for emost effective plant growth-promoting bacterium under in vitro conditions [18].

Maximum colonization of T.viride and the bacterial count was observed in dual inoculated plants which can be due to their synergistic effect. This is attributed to the fact that mycorrhizal root tips support slightly higher populations of Pseudomonas than non-mycorrhizal root tips, possibly due to the provision of additional colonization sites or altered root exudation in mycorrhizosphere [19]. The increase in survival rate could also be due to the synergistic effect of $T$. viride with $P$. fluorescens which can solubilize additional phosphorus within the soil by producing organic acids [20]. Similarly, T. viride or P. fluorescence alone and also their combined effect on growth improvement was also reported by other workers [21,22]. Von Alten emphasized the use of mycorrhizae-helping bacteria (MHB) for enhancement of growth of the plants [23]. He reported that rhizosphere strains of Bacillus mycoides and P.fluorescens promoted AMF formation in various crop plants by improving the susceptibility of roots to AMF. It was reported that combined use of Glomus mosseae and $P$. fluorescens caused a good increase in plant growth of tomato as compared to individual application of both the organisms [24]. Plant- microbial mediated interactions among P.fluorescens, Rhizobium leguminosarum, and AMF on Pea was studied [25]. They found that $P$. fluorescens F 113 enhanced nodulation by Rhizobium fourfold by producing larger and highly pigmented nodules.

Other rhizosphere microorganisms which are known to act as a phytostimulators or which possess antagonistic activities toward plant pathogens can also be used alone or in conjunction with arbuscular mycorrhizal fungi for biotizing microplants. Among these beneficial microorganisms, there are both bacteria like Pseudomonas spp. , Bacillus spp., and fungi such as Gliocadium spp. and Trichoderma spp [26,27]. Similar reports of plant biotization with more than one microorganism are reported in some species [28-31].
Biotization with friendly associates like AMF, symbiotic endophytes or pathogen antagonists also protect the juvenile axenic plants from the infestation of the harmful saprophytes [32,33]. The colonization of Glomus and Trichoderma species is also known to reduce the osmotic potential of plants [34-37]. Populations of microbes having antagonistic activity against soil-borne pathogens can be stimulated by mycorrhization [38]. The reason for this effect is unknown but other rhizosphere microbe communities can also be modified by mycorrhizal fungi [39]. These observations indicate that mycorrhizal fungi can structure communities of beneficial soil microbes around roots and so could condition the results of multi microbial biotization.

In the present study, dual inoculations showed a significant number of lateral rootlets, increase in root length as compared to single inoculations due to the presence of beneficial microflora, which may have produced growth-promoting substances. Better root system helped in more nutrient uptake, which resulted in healthy plants with more shoot biomass, as healthy roots result in a healthy plant. Similar findings have been made using $P$. fluorescens Aur6 and ectomycorrhizal fungus, Suillus granulatus, as dual inoculants in Pinus halepensis [40]. Significantly higher root-shoot biomass in different crops like Maize, Bacopa, Poplar with dual inoculation has also been reported [41].

When transplanted to the greenhouse conditions, the $P$. fluorescens inoculated A.amara plantlets showed better growth and $55 \%$ survival percentage. Similar results were reported from greenhouse experiments of plants derived from dual cultures of potato and the pseudomonad bacterium which had a larger root system, set stolons and tuberized earlier, and gave better tuber yield than non- bacterized controls [42]. Both in vitro and ex vitro benefits of bacterization depended on plant species, cultivar, and growth conditions [43,44].

Dramatic root growth promotion was induced by a pseudomonad bacterium co-cultured with herbaceous plants, potato, tomato, watermelon, cucumber and pepper [44-46]. Significant elongation of roots in Brassica campestris seedlings by a strain of Pseudomonas putida was studied [47]. In vitro co-cultivation of soybean cotyledon explants with two strains of Pseudomonas maltophilia, stimulated the development of nodular callus with high regeneration potential [48]. In a study, shoot explant bacterization of Oregano with a Pseudomonas spp. prevented vitrification [49]. The Oregano plantlets were co-cultured with the Pseudomonas spp. had lowered water content and contained more phenolics and chlorophyll than non bacterized controls. Bacterized plantlets were greener, had elevated levels of cytokinins [45], phenylalanine ammonia-lyase, free phenolics and contained more lignin [50]. It was also reported that $P$. fluorescens can produce plant growth- 
promoting substances and some secondary metabolites which enhance nutrient uptake and plant growth [51].

When transplanted to the greenhouse conditions, the T. viride inoculated A. amara plantlets showed better growth and $63 \%$ survival percentage. Reports show that a dip in $T$. viridae had stimulated root proliferation in Neem by its ability to colonize at the base of micro shoots [52]. Harman reported that bio-control agent $T$. viride is a good additive to greenhouse potting mix [53]. It can reduce fungicide use in greenhouses by limiting root- borne diseases and protect transplants in the field by its ability to stimulate root proliferation and root colonization.

The University of Connecticut reports that $T$. viride grows on the surface of roots where it helps in disease control and enhances root growth. Once Trichoderma colonizes the root, it improves growth in two ways, first, it kills pathogenic fungi causing root rot and, secondly, it protects the roots from physical stresses enabling them to grow faster. It was reported that $T$. viride when applied alone to Broccoli, showed maximum root $\mathrm{P}$ and shoot $\mathrm{N}$ content [54]. The enhanced vegetative growth of Broccoli in Trichoderma treated plants could be due to the root colonizing ability of the fungus that resulted in better nutrient absorption through increased root biomass.

Thus biotization of micropropagated A.amara plantlets with beneficial microflora as increased plant survival and growth which clearly explains its potential use as growthpromoting agents. The development of multi microbial biotization that combines microbes with complementary functions for promoting plant growth and health is, therefore, a more promising technology. However, its application appears more difficult and requires considerable progress in our knowledge about functional compatibility between beneficial microbes in the rhizosphere. The induction of stress resistance in plant propagules produced in vitro before transplanting is a primary target of several research groups attempting the utilization of microbial inoculants in micropropagation $[34,45,55]$.

\section{CONCLUSION AND FUTURE SCOPE}

To our knowledge, our study is the first to describe biohardening of A.amara by - Pseudomonas fluorescens and Trichoderma viride. Biotization of micropropagated A.amara plantlets with dual inoculation of T.viride and $P$. fluorescens increased maximum plant survival (82\%) than inoculation with either T.viride $(63 \%)$ or $P$. fluorescens $(55 \%)$. Plant survival was observed maximum in dual inoculation, this must be due to the positive interaction between T.viride and $P$. fluorescens and their ability to improve stress tolerance by protecting them from subsequent 'transplantation shock'. Biotized plants showed root colonization of T.viride and exhibited the presence of hyphae in roots as well as rhizospheric colonization of $P$. fluorescens. The increase in survival rate could also be due to the synergistic effect of $T$. viride with $P$. fluorescens which can solubilize additional phosphorus within the soil by producing organic acids. Biotized field-grown plants exhibited an increase in root length, the number of lateral roots, shoot length, leaf number and plant biomass in dual inoculation which were significantly better over single inoculation as well as uninoculated control.

Thus microplants represent an ideal material for developing basic research on microbial biotization. Application of multi microbial biotization to microplants requires knowledge and understanding of the compatibility between different beneficial microorganisms in their interaction within the mycorrhizosphere, rhizosphere, and rhizoplane. Thus biological hardening envisages physical, chemical and environmental conditioning of the micropropagated plantlets. Development of new culture methods allowing the establishment of stable associations between plants and beneficial organisms in vitro and ex vitro at the molecular level and understanding the mechanisms of signal recognition and transduction under different environments are probably the important areas of research to be explored.

\section{ACKNOWLEDGMENT}

G.I. is highly thankful to University Grants Commission for the financial support (UGC-SERO) under Minor Research Project (UGC MRP.F No-4814/14). PSB is UGC-Assistant Professor and is acknowledging the UGC for selecting her under Faculty Recharge Program.

\section{REFERENCES}

[1]. U.K.Tomar, S.C. Gupta, "In vitro plant regeneration of leguminous trees (Albizia spp)”. Plant Cell Reports, Vol.7 (1988) 385.

[2]. Ramamurthy N, Savithramma N, Shoot bud regeneration from leaf explants of Albizia amara Boiv. Indian J. Plant Physiol, 8 (2003) 372.

[3]. Indravathi $\mathrm{G} \&$ Pullaiah $\mathrm{T}$, Invitro propagation studies of Albizia amara. African Journal of Plant Science, 7 (2013) 1.

[4]. Trouvelot A, Kough JL, Gianinazzi-Pearson V, Mesure du taux de ycorrhization VA d'un systeme radiculaire.Recherche de methods d'estimation ayant une signification fonctionnelle. In: Physiological and general aspects of mycorrhizae. Paris: (Ed.Gianinazzi Pearson V, Gianinazzi S, INRA) 1986,217.

[5]. Morandi D, Gianinazzi S \& Gianinazzi-Pearson V, Intérêt de l'endomycorhization dans la reprise et la croissance du Framboisier issu de multiplication vegetative in vitro. Ann. Amélior. Plantes , 29 (1979) 623.

[6]. Ravolanirina F, Gianinazzi S, Trouvelot A \& Carre M, Production of endomycorrhizal explants of micropropagated grapevine rootstocks. Agriculture, Ecosyst. Envir. 29 (1989) 323.

[7]. Guillemin JP, Gianinazzi S \& Trouvelot A, Screening of arbuscular mycorrhizal fungi for the establishment of micropropagated pineapple plants. Agronomie, 12 (1992) 831.

[8]. Morte MA, Diaz G \& Honrubia M, Effect of arbuscular mycorrhizal inoculation on micropropagated Tetraclinis articulata growth and survival. Agronomie ,16 (1996) 633.

[9]. Vestberg M \& Uosukainen M, Effect of AMF inoculation on rooting and subsequent growth of cuttings and micro cuttings of greenhouse 
rose Mercedes. In: Novel biotechnological approaches to plant production: from sterile root to mycorrhizosphere (Joint COST action 8.21 and 8.22, Pisa, Italy) 1996,46 .

[10]. Ravolanirina, F.; Blal, B.; Gianinazzi, S.; Gianinazzi-Pearson, V. Mise au point d'une methode rapide d'endomycorhization de vitro plants.Fruits 44:165 $\pm 170 ; 1989 \mathrm{~b}$.

[11]. Schubert A, Mazzitelli M, Ariusso O \& Eynard I, Effects of vesiculararbuscular mycorrhizal fungi on micropropagated grapevines: influence of endophyte strain, $\mathrm{P}$ fertilization, and growth medium. Vitis 29 (1990) 5 .

[12]. Lovato PE, Schuepp H, Trouvelot A \& Gianinazzi A, Application of arbuscular mycorrhizal fungi (AMF) in the orchard and ornamental plants, In Mycorrhiza- structures, function, molecular biology, and biotechnology,(2nd Edn, Springer, Berlin) 1999, 443.

[13]. McCown BH, Woody Ornamentals, Shade Trees, and Conifers. In: Tissue culture as a plant production system for horticulture crops (Dordrecht. The Netherlands: Martins Nijhoff) 1986, 333.

[14]. Rohr R, Iliev I, Scaltsoyinnes A \& Tsoulpha P, Acclimatization of micropropagated forest trees. ActaHortic , 616 (2003) 59.

[15]. Phillips JM \& Hayman DS, Improved procedures for clearing and staining parasitic and vesicular-arbuscular mycorrhizal fungi for rapid assessment of infection, Trans Br Mycol Soc, 55 (1970) 158.

[16]. Johnson LF, Curl EA, Methods for Research on the Ecology of SoilBorne Plant Pathogens. (Minneapolis: Burgess) 1972.

[17]. Hazarika BN, Acclimatization of tissue-cultured plants.Curr Sci, 85 (2003) 1704.

[18]. Frommel MI, Nowak J \& Lazarovits G, Treatment of potato tubers with growth-promoting Pseudomonas spp. Plant growth responses and bacterium distributing in the rhizosphere.Plant Soil, 150 (1993) 51.

[19]. Linderman RG \& Paulitz TC, Mycorrhizal-rhizobacterial interactions.In: Biological control of soil-borne plant pathogens, (Ed. Homby D, CAB International, Wallington) 1990, 262.

[20]. Avis TJ, Gravel V, Antoun H \& Tweddell RS, Multifaceted beneficial effects of rhizosphere microorganisms on plant health and productivity. Soil Biology and Biochemistry, 40 (2008) 1733.

[21]. Shanmugaiah V, Balasubramanian N, Gomathinayagam S, Manoharan PT \& Rajendran A, Effect of a single application of Trichoderma viride and Pseudomonasfluorescens on growth promotion in cotton plants. African Journal of Agricultural Research, 4 (2009) 1220.

[22]. Mishra DS, Gupta AK, Prajapati CR, and Singh US, Combination of fungal and bacterial antagonists for management of root and stem rot disease of soybean. Pakistan Journal Botany, 43 (2011) 2569.

[23]. Von A. State of commercial use of AMF-inoculum in Germany. In: Arbuscular mycorrhizas in sustainable soil-plant systems- Report of 1997 activities, Cost Action (Ed. Gianinazzi S, \& Schuepp H, 821, Iceland) $1998,153$.

[24]. Siddiqui ZA \& Mahmood I, Effect of plant growth-promoting bacterium, an AM fungus and soil types on the morphometrics and reproduction of Meloidogyne javanica on tomato. Appl. Soil Ecol, 8 (1998) 77.

[25]. Andrade G, De Leij FAAM, Lynch JM, Plant mediated interactions between Pseudomonas fluorescens, Rhizobium leguminosarum and arbuscular mycorrhizae on the pea. Lett. Appl. Microbiol. 26 (1998) 311.

[26]. Kloepper JW, Zablotowick RM, Tipping EM \& Lifshitz R, Plant growth promotion mediated by bacterial rhizosphere colonizers. In: The Rhizosphere and Plant Growth..(Ed. Keister DL \& Cregan PD; Kluwer, Dordrecht)1991,315.

[27]. Linderman RG, Role of VAM fungi in biocontrol. In: Mycorrhizae and plant health. (Pfleger FL, Linderman RG; St. Paul, MN: APS Press The American Phytopathological Society) 1994, 344.

[28]. Calvet C, Pera J \& Barea JM, Interactions of Trichoderma spp. with Glomus mosseae and two wilt pathogenic fungi. Agri. Ecosystem Environ, 29 (1990) 59.

[29]. Datnoff LE, Nemec S \& Pernezny K, Biological control of Fusarium crown and root rot of tomato in Florida using Trichoderma harzianum and Glomus intraradices. Biol. Control, 5 (1995) 427.

[30]. Azcon Aguilar C, Cantos M, Troncoso A \& Barea J, Beneficial effect of arbuscular mycorrhizas on acclimatization of micropropagated cassava plantlets. Sci Hortic, 72 (1997) 63.
[31]. Barea JM, Rhizosphere, and mycorrhiza of field crops. (Ed. Balazs, Galante E, Lynch JM, Schepers JS, Toutan JP, Werner D \& Werry PA), 2000,110.

[32]. Lovato PE, Gianinazzi-Pearson V, Trouvelot A, Gianinazzi S, The state of mycorrhizas and micropropagation.Adv. Hort. Sci , 10 (1996) 46.

[33]. Pandey A, Palni LMS, Beg N, Biological hardening of tissue culture raised tea plants through rhizosphere bacteria. Biotechnol.Lett. 22 (2000) 1087.

[34]. Elmeskaoui A, Damont JP, Poulin MJ, Piche Y, Desjardins Y, A tripartite culture system for endomycorrhizal inoculation of micropropagated strawberry plantlets in vitro. Mycorrhiza 5 (1995) 313.

[35]. Varma A \& Schuepp H, Influence of mycorrhization on the growth of micropropagated plants. In: Mukerji KG (Ed.) Concepts in Mycorrhizal Research (Kluwer Academic Publishers, London), 1996, 13.

[36]. Hernandez CS, Piche Y \& Desjardins Y, Water relations of whole strawberry plantlets in vitro inoculated with Glomus intraradices in a tripartite culture system. Plant Sci. 143(1999) 81.

[37]. Sahay NS, Varma A, Piriformospora indica: a new biological hardening tool for micropropagated plants.FEMS Microbiol. Lett, 181 (1999) 297.

[38]. Linderman RG, Effects of mycorrhizas on plant tolerance to diseases. In: Arbuscular Mycorrhizas: Physiology and Function (Ed. Kapulnik Y \& Douds DD; Kluwer Academic Publishers, Dordrecht) 2000,345 .

[39]. Barea JM, Azcon-Aguilar C \& Azcon R. Interactions between mycorrhizal fungi and rhizosphere microorganisms within the context of sustainable soil-plant systems. In: Multitrophic Interactions in Terrestrial Systems (Ed. Gange AC \& Brown VK; Blackwell, Oxford, UK) 1996,65.

[40]. Rincon A, Diez BR, Fraile GS, Garcia L, Pascual MF, et al, Colonization of Pinus halepensis roots by Pseudomonas fluorescens and interaction with the ectomycorrhizal fungus Suillus granulatus. FEMS Microbiol Ecol, 51 (2005) 303.

[41]. Varma A, Sahay NS, Butehom B \& Franken P, Piriformospora indica a cultivable plant-growth-promoting root endophyte with similarities to arbuscular mycorrhizal fungi. Appl Environ Microbiol, 65 (1999) 2741.

[42]. Dunbar C, Utilization of seaweed extract and plant growth-promoting rhizobacterium in greenhouse production of potato minitubers, M.Sc thesis, Dalhousie University, Halifax, NS, Canada, 1997.

[43]. Lazarovits G \& Nowak J, Rhizobacteria for improvement of plant growth and establishment. Hort Science, 32 (1997) 188.

[44]. Pillay VK \& Nowak J, Inoculum density, temperature and genotype effects on epiphytic and endophytic colonization and in-vitro growth promotion of tomato by pseudomonas. Can .J.Microbiol,43 (1997) 354.

[45]. Nowak J, Review benefits of in vitro "biotization" of plant tissue cultures with microbial inoculants. In vitro Cell Dev Biol Plant, 34 (1998) 122.

[46]. Burns AJ \& Schwarz OJ, Bacterial stimulation of adventitious rooting on in vitro cultured slash pine seedling explants. Plant Cell Rep, 15 (1996) 405.

[47]. Lifshitz R, Kloepper JW et al., Growth promotion of canola seedlings by a strain of Pseudomonas putida under gnotobiotic conditions.Can .J.Microbiol, 33 (1987) 390.

[48]. Yang YS, Wada K, Goto M, et al., In vitro formation of nodular calli in soya bean induced by co-cultivated Pseudomonas maltophilia.Japan.J.Breed, 41 (1991) 595.

[49]. Shetty K, Curtis OF, Levin RE.; et al. Prevention of vitrification associated with invitro shoot culture of oregano by Pseudomonas species. J.Plant Physiol, 147 (1995) 447.

[50]. Richards J, Induced resistance responses in potato inoculated in vitro with plant growth-promoting pseudomonad bacterium, M.Sc. thesis, Dalhousie University, Halifax, NS, Canada;1997.

[51]. Burr TJ, Schroth MN, Suslow TV, Increased potato yields by treatment of seed pieces scientific strains of Pseudomonas fluorescens and P. putida. Phytopathology, 68 (1978) 1377. 
[52]. Lavanya M, Venkateshwarlu B \& Devi BP Acclimatization of neem micro shoots adaptable to semi-sterile conditions. Ind J Biotechnol, 8 (2009) 218.

[53]. Harman GE, Trichoderma for biocontrol of plant pathogens. Basic research to commercialized products. Cornell communities, conference on biological control, (1996) 1.

[54]. John RP, Tyagi RD, Prevost D, Brar SK, Pouleur S \& Surampalli RY, Mycoparasitic Trichoderma viride as a biocontrol agent against Fusarium oxysporum.sp. adzuki and Pythium arrhenomanes and as a growth promoter of soybean. Crop Protection, 29 (2010) 1452.

[55]. Hooker JE, Gianinazzi S \& Vest Berg M et al ., The application of arbuscular mycorrhizal fungi to micropropagation systems: an opportunity to reduce chemical inputs. Agric.Sci.Finland, 3 (1994) 227

\section{AUTHORS PROFILE}

Ms. G Indravathi completed M.Sc., M.Phil., from SK University, Anantapuram in 2002 \& 2005. She is currently working as Asst.Professor in Department of Biotechnology from KVR Govt.College for Women(A), Kurnool since 2008. She is a Life member of ISCA and BRSI since 2015. She has published 3 research papers in reputed international journals and presented papers in national seminars and conferences. She organized two national level seminars sponsored by APSCHE, Hyderabad, and UGC-SERO in 2011 and 2015 respectively. She has completed one minor research project sponsored by UGC-SERO in 2014-2016. Her main research work focuses on Plant tissue culture and acclimatization studies. She has 15 years of teaching experience and 5 years of research experience.

Table 1 - Effect of bio inoculants on growth parameters of micropropagated Albizia amara

\begin{tabular}{|c|c|c|c|c|c|c|}
\hline Treatment & $\begin{array}{c}\text { \%Survival after } \\
\text { 60 Days }\end{array}$ & $\begin{array}{c}\text { Root length } \\
(\mathbf{c m}) \begin{array}{c}\text { Mean } \pm \\
\text { S.D }\end{array}\end{array}$ & $\begin{array}{c}\text { Shoot length } \\
(\mathbf{c m}) \begin{array}{c}\text { Mean } \pm \\
\text { S.D }\end{array}\end{array}$ & $\begin{array}{c}\text { No. of leaves } \\
\text { Mean } \pm \text { S.D }\end{array}$ & $\begin{array}{c}\text { Total plant } \\
\text { biomass } \\
\text { Fresh Wt (g) } \\
\text { Mean } \pm \text { S.D }\end{array}$ & $\begin{array}{c}\text { Total plant } \\
\text { biomass } \\
\text { Dry Wt (g) } \\
\text { Mean } \pm \text { S.D }\end{array}$ \\
\hline Control & 5.0 & $2.32 \pm 0.41$ & $4.24 \pm 0.25$ & $2.32 \pm 0.21$ & $0.32 \pm 0.11$ & $0.06 \pm 0.10$ \\
\hline P.fluorescens & 55.0 & $4.84 \pm 0.5$ & $7.85 \pm 0.35$ & $4.83 \pm 0.18$ & $0.79 \pm 0.15$ & $0.18 \pm 0.11$ \\
\hline T.viride & 63.0 & $6.95 \pm 0.53$ & $9.56 \pm 0.24$ & $4.24 \pm 0.15$ & $0.92 \pm 0.14$ & $0.20 \pm 0.12$ \\
\hline $\begin{array}{c}\text { P.fluorescens }+ \\
\text { T.viride }\end{array}$ & 82.0 & $10.86 \pm 0.35$ & $12.56 \pm 0.28$ & $6.85 \pm 0.15$ & $1.12 \pm 0.15$ & $0.28 \pm 0.11$ \\
\hline
\end{tabular}

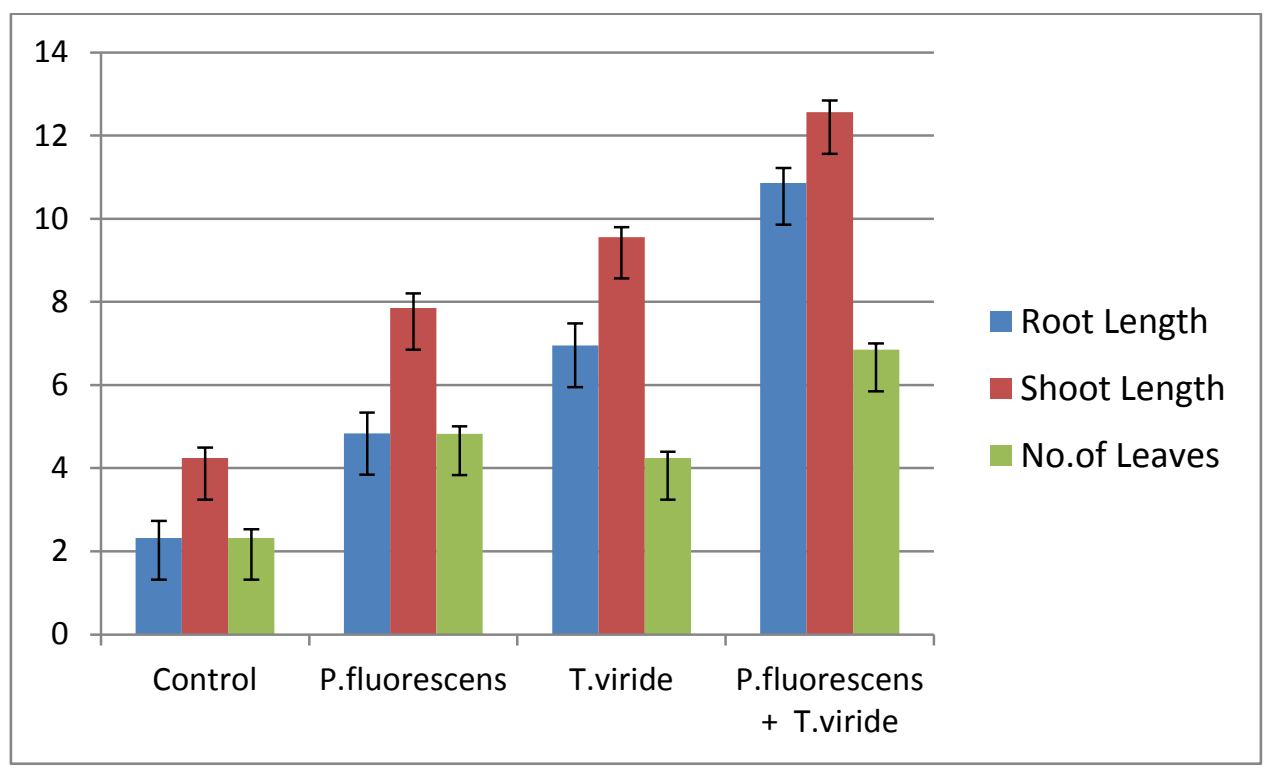

Figure 1: Effect of bio inoculants on growth parameters of micropropagated Albizia amara 


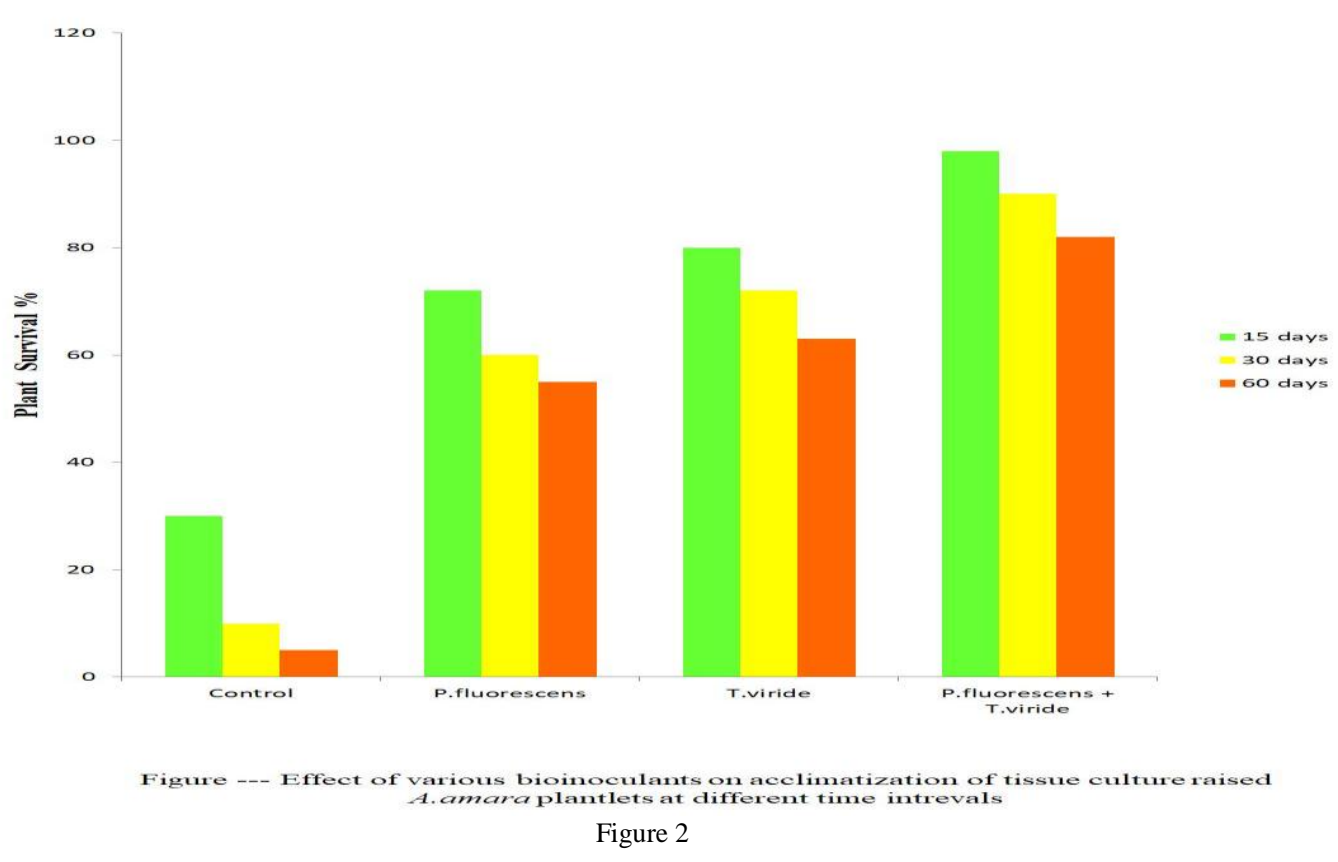

